\title{
APRENDIZAGENS DO E NO FUTEBOL: sobre os ensaios e a constituição da habilidade
}

Eliene Lopes Faria

\section{RESUMO}

Este artigo aborda a aprendizagem de uma prática muito popular no Brasil: o futebol. Produzido a partir de pesquisa etnográfica (em um bairro de Belo Horizonte/BR) em diálogo com a antropologia, o estudo desvelou elementos que envolvem a aprendizagem nesse esporte: os contextos de produção e os modos de participação; as relações de poder/aprendizagem entre novatos e veteranos; as mudanças nas formas de participação; a constituição de identidades; os ensaios futebolísticos como contextos de aprendizagem. A centralidade/densidade das aprendizagens constituídas nos ensaios futebolísticos (repetidos exercícios dos praticantes com a bola) permitiu recortar essas práticas como foco. Neste artigo, essas práticas foram colocadas em dois grupos: ensaios "solo" (quando um praticante se envolve na produção de movimentos futebolísticos com a bola) e os ensaios "guiados" (quando mais de um praticante está envolvido na produção de movimentos futebolísticos).

Palavras chave: Futebol. Aprendizagem. Ensaios

1 Doutora em Educação. Professora de Educação Física do Colégio Técnico da Universidade Federal de Minas Gerais (UFMG). Belo Horizonte/Minas Gerais, Brasil. E-mail: elienelopesfaria@gmail.com 


\title{
LEARNING OF AND IN SOCCER: about the trials and the constitution of skill
}

\begin{abstract}
This paper discusses the learning of a practice very popular in Brazil: soccer. Made from ethnographic research (in Belo Horizonte / BR) in dialogue with the anthropology of learning, the study unveiled elements that involve learning / participation in this sport: the contexts of production and modes of participation, power relations/learning among novice and veteran, the changes in the forms of participation, the constitution of identities, football trials as learning contexts. The centrality/density of learning constituted in trials (repeated exercises of the practitioners with the ball) allowed to put such practices as focus. In this article, these practices were put into two groups: trials "solo" (when a practitioner engages in the production of football moves with the ball) and the essays "guided" (when more than one practitioner is involved in producing movements football).
\end{abstract}

Keywords: Football. Learning. Trials

\section{APRENDIZAJE DE Y EL FÚTBOL: en ensayos y la constitución la capacidad}

\section{RESUMEN}

El artículo discute un aprendizaje de una práctica popular en Brasil: el fútbol. Producido a partir de una etnografica (Belo Horizonte/BR) en diálogo con una antropología, el estudio reveló elementos de aprendizaje de este deporte: los contextos producción y modos de participación; las relaciones de poder / aprendizaje entre los principiantes y veteranos; los cambios en las formas de participación; la constitución de las identidades; los ensayos como contextos de aprendizaje. La centralidad/densidad de aprendizaje incorporado en los ensayos de fútbol (repetidos ejercicios que practican con la pelota) permitido poner estas prácticas en el foco. En este artículo, estas prácticas fueron colocados en dos grupos: ensayos "Solo" (cuando un practicante se involucra en la producción de movimientos con la pelota de fútbol) y ensayos "dirigido" (cuando más de un practicante está involucrado en la producción de movimientos de fútbol).

Palabras clave: Fútbol. Aprendizaje. Ensayos 


\section{INTRODUÇÃO}

Este trabalho aborda os modos de aprendizagem de uma prática muito popular no Brasil: o futebol. Elaborado a partir de uma incursão etnográfica em diálogo com a produção teórica da antropologia - sobretudo a abordagem situada de Lave e Wenger $(1991)^{2}$ e a abordagem ecológica da cultura de Ingold $(2000,2001)^{3}$ - o trabalho descreve os modos cotidianos de aprendizagem desse esporte.

As características do futebol (a sua produção cotidiana, a prática de ensino reduzida, a aprendizagem a partir do envolvimento crescente na prática, os diferentes níveis de participação e os aspectos identitários envolvidos) favoreceram o seu estudo a partir da abordagem da aprendizagem situada de Lave e Wenger (1991). Operando com a mudança de foco proposta pelos autores - do indivíduo, como aprendiz, para a aprendizagem como participação no mundo social - essa perspectiva possibilitou dar relevo à dimensão social da aprendizagem destacando as interações que levam a pessoa/sujeito a aprender. Portanto, essa abordagem ensejou possibilidades de análise de uma dinâmica em que a aprendizagem é inseparável da prática social cotidiana. Permitiu ainda: abordar a aprendizagem como constituição de habilidade e de identidades; compreender mais sobre os processos cotidianos de aprendizagem do futebol; questionar a onipresença das relações mestre/aprendiz como traço característico da aprendizagem e explicitar outras dinâmicas sociais (invisíveis) de aprendizagem.

Para abordar o tema, contudo, foi preciso superar a ideia de aprendizagem de gestos (descontextualizados, sem significados e sem história). Parti do princípio de que as práticas esportivas não são aprendidas apenas como gestos motores, pois considero que os esportes são práticas culturais e, desse modo, cheios de significados. ${ }^{4}$ É preciso salientar, entretanto, que a complexidade da prática futebolística mostrou que aprender (a cultura) não se esgota na consideração de gestos motores e significados, mas que, no processo de incorporação da prática social, outros aspectos estão em jogo. Portanto, esta pesquisa procurou dar relevo ao conjunto de elementos que envolvem a aprendizagem desse esporte, ou seja, de significados, disposições corporais, tipos de atenção, identidades, emoções e conhecimentos que caracterizam a prática. Em síntese, neste trabalho a experiência foi tomada como percurso de aprendizagem e o conhecimento como fundado na habilidade. Assim, ao lado do conceito de participação (LAVE e WENGER, 1991) trouxe para o centro das análises a noção de habilidade de Ingold (2000, 2001) - como campo total de relações constituídas que no caso do futebol envolvem o jogador, a bola, o outro, o ambiente - , buscando descrever esse campo de relações ${ }^{5}$.

2 A aprendizagem como "atividade situada" é a definição central do processo que Lave \& Wenger (1991) denominam Legitimate Peripheral Participation - processo pelo qual os aprendizes participam em comunidades de prática e que o domínio do conhecimento e das habilidades requer um mover-se para a participação plena nas práticas socioculturais.

3 Abordagem que busca superar a oposição entre natureza e cultura.

4 Posição que partilho com outros estudiosos no campo da Educação Física.

5 A adoção do conceito de Skill (traduzido nesse artigo como habilidade e colocado em itálico por fazer referencia à conceituação de Ingold), entretanto, requer atenção para os seus limites. Para Sauchuck (2015), "não seria 
O trabalho é produto de uma pesquisa etnográfica realizada com os jovens praticantes do futebol em um bairro de Belo Horizonte em 2005/2006 ${ }^{6}$ - contexto dotado de espaços diversificados para a aprendizagem do futebol (escola pública, "escolinhas" de esportes, projetos sociais, campos de várzea, praças esportivas, terrenos baldios, ruas, becos, etc.). A opção por investigar as práticas de futebol de jovens da periferia da cidade tornou-se relevante. Primeiro, porque os jovens em idade de escolarização têm intensificação do acesso às práticas esportivas/futebolísticas nas aulas de Educação Física e ampliação da sua vivência em outros tempos escolares (recreios, entradas e saídas da escola) e sociais (fora da escola). Além disso, porque na periferia (ao contrário dos bairros mais centrais de Belo Horizonte) se multiplicam os espaços/tempos de produção do jogo: na escola pública (que é a que garante acesso às camadas populares), nos projetos sociais e "escolinhas" de futebol, nas peladas nas imediações do bairro, nos times amadores de futebol de várzea, nas torcidas dos times profissionais de futebol, etc. O futebol é, portanto, parte da sociabilidade.

Seguindo as orientações propostas na teoria da aprendizagem situada de Lave e Wenger (1991), foi escolhido um contexto social no qual os recursos para a aprendizagem do futebol vinham de várias fontes (não apenas da atividade pedagógica); em que era possível observar a ocorrência de intricada estrutura de aprendizagem do futebol; em que a prática criava um currículo potencial (de aprendizagem), no sentido amplo; enfim, em que o futebol fazia parte do dia-a-dia dos jovens. Focando nas práticas futebolísticas juvenis busquei dar relevo aos aspectos sutis e invisíveis que permitissem compreender seus modos de aprendizagem.

Situado na região nordeste de Belo Horizonte, às margens do Anel Rodoviário (BR-381), o bairro escolhido para a pesquisa é eminentemente residencial. Diferenças

exagerado dizer que Ingold desenvolve a mais potente formulação acerca da aprendizagem na antropologia depois dos múltiplos efeitos gerados pela voga do interesse mais geral pela "prática" e pela "experiência". Para o autor (2015. p. 122), entretanto, para avançar nas contribuição de Ingold "é necessário, porém, ver um pouco mais de perto a noção de skill, que está na base dessas proposições". Localizando a potência da noção de skill de Ingold na tensão que ela localiza entre os polos do organismo-pessoa e do ambiente, Sauchuck (2015. p.124) afirma, entretanto, "que no pensamento ingoldiano, o polo organismo-pessoa é muito forte, central" e que, desse modo, a relação com o ambiente (e o seu sentido) orbita "em torno da presença desse organismopessoa". Para Sauchuck (p.126) "se a noção de skill consegue sublinhar de modo absolutamente relacional (e para além do anthropos) a instituição das ações humanas nesses contextos, ela parece menos capaz de aguçar a percepção etnográfica para as diferentes localizações (e configurações, ou gêneses) dos humanos no interior de sistemas de relações".

6 Realizei o processo de incursão no campo da pesquisa, considerando a necessidade de reconhecer a heterogeneidade dos interlocutores: os jovens. Busquei nos estudos sobre os jovens (MELUCCI, 1997; SPÓSITO, 1997; dentre outros) compreender juventude como categoria não-homogênea. Como afirma Melucci (1997, p.9), "a juventude não é mais somente uma condição biológica, mas uma definição cultural". Constituída pela faixa de 15 a 24 anos nas orientações de trabalhos na área demográfica, essa classificação de juventude é questionada por Spósito (1997, p.39): [...] para o conjunto da sociedade brasileira, a tendência maior é a antecipação do início da vida juvenil para antes dos 15 anos, na medida em que certas características de autonomia e inserção em atividades no mundo do trabalho - típicos do momento definido como a transição da situação de dependência da criança para a autonomia completa do adulto - torna-se horizonte imediato para grande parcela dos setores empobrecidos". A partir das reflexões apresentadas por Spósito (1997), tornase possível afirmar que a categoria juventude não é estável e linear, mas histórica. Assim, juventude não é um dado. Ela é, antes de tudo, uma construção carregada de significação cultural. 
socioeconômicas, que revelam aspectos importantes dos modos de vida dos seus moradores, podem ser observadas na arquitetura local (casas grandes de quintais amplos, nas proximidades da avenida principal, e barracos de lona e/ou madeira, nas imediações do Anel Rodoviário) e na distribuição espacial. Essas diferenças podem ser observadas também nas condições materiais de vida dos moradores. Enquanto os que moram na parte central do bairro têm acesso à água, esgoto, luz e outros bens, muitos que ocupam o entorno do Anel Rodoviário e proximidades convivem com a precariedade, com desemprego, moradias insalubres (umidade, pouca luz e espaço), barulho, lixo, inundações, chuva. Para estes, o cotidiano tem uma dimensão pública acentuada. Isso porque é na rua que crianças, mulheres e homens passam grande parte do tempo (para lavar roupas, para brincar, para beber cerveja, para namorar, para conversar, para escapar do calor, para olhar o movimento dos que ali fazem ponto de passagem). O cotidiano do bairro é, contudo, dinâmico e, se os lugares são fixos, as pessoas não. Jovens, crianças e adultos deste bairro e dos vizinhos se misturam no cotidiano na escola, na Praça de Esportes, no campo de futebol, no mercadinho, no bar, na rua - sobretudo nas práticas de futebol.

Antes de adentrar na descrição dos ensaios futebolísticos (como modo de aprendizagem do futebol no bairro pesquisado), é importante destacar, porém, que para o conceito de participação de Lave e Wenger (1991), a noção de legitimidade é central. Considerada uma abertura, um modo de ganhar acesso às fontes de entendimento, ela é uma condição sine que non para a participação e, consequentemente, para o conhecimento, ou seja, a estrutura social da prática, "suas relações de poder e suas condições para a legitimidade definem possibilidades para a aprendizagem". Tomando como referência essas reflexões dos autores (1991), busquei compreender o universo de aprendizagem do futebol como constituído por praticantes que possuem legitimidade de participação.

Desvelando os contextos de produção do futebol no bairro, pude percebê-los, entretanto, como contextos generificados. A pesquisa de campo destacou a ampla participação masculina no futebol (FARIA; FONTES, 2008). Isso porque as práticas futebolísticas que ocorriam cotidianamente eram marcadas por amplo engajamento dos jovens do sexo masculino e pela ausência/exclusão das mulheres (com exceção das aulas de Educação Física). No bairro, para se tornar participante periférico do futebol, o mais básico requisito era ser do sexo masculino. Essa legitimidade da participação dos homens não indicava, entretanto, homogeneidade e permanência na prática: trajetórias diferentes eram constituídas nas e das práticas de futebol.

O texto que segue (recorte da tese de doutorado) é uma descrição de como os jovens do sexo masculino, a partir do envolvimento crescente nos exercícios/ensaios (denominação eleita a partir de um diálogo com INGOLD, 2001) futebolísticos cotidianos aprendiam/incorporavam importantes aspectos do jogo. Iniciados na infância, os ensaios futebolísticos (ou múltiplas maneiras de exercitação dos praticantes com a bola) constituem práticas masculinas que se desdobram no decorrer de toda a participação na prática social ${ }^{7}$.

7 Para preservar os sujeitos da pesquisa foram utilizados nomes fictícios. 


\section{"Chutando que você aprende": os ensaios de futebol}

No cotidiano do bairro pesquisado, para além do jogo em si, os jovens realizavam múltiplas práticas de futebol em diferentes contextos. Nas aulas de Educação Física, alunos que ficavam na de fora aproveitavam a oportunidade para "experimentar" a bola nas laterais da quadra ${ }^{8}$. Nas imediações do bairro (em casa, na rua, na praça), jovens realizavam cotidianamente manobras futebolísticas. No campo de futebol, jovens que observavam as práticas (os treinos de futebol dos times do bairro e dos alunos do Projeto Social, as práticas de futebol de lazer de grupos e os jogos amistosos e campeonatos no fim de semana) exploravam movimentos do corpo com a bola e/ou aproveitavam os intervalos dos jogos para ocupar o campo de futebol com um "bate-bola" (situações em que jovens, crianças e adultos se apropriavam do espaço "sagrado" do jogo de futebol no bairro). Como afirma Damo (2005, p.166), o aprendizado do futebol no bairro não era "instrumental, consciente e desconexo da sociabilidade como um todo".

Quando dois/três jovens se encontravam no entorno do campo, na quadra ou no pátio da EECJP, na rua ou na Praça de Esportes do bairro, e algum deles tinha uma bola (ou qualquer objeto que a substituísse), imediatamente se iniciava uma movimentação. Entre praticantes de diferentes idades (mas, principalmente, jovens) o futebol se desdobrava em repetidas execuções de pênaltis com ou sem goleiro, de lançamentos da bola na área de gol para a finalização do colega, de tentativas de realização de diferentes gols (de bicicleta, de cabeça etc.), de chutes de escanteio direto a gol ou para o colega finalizar a jogada com a cabeça ou de voleio (geralmente os mais audaciosos), de pedaladas (correr com a bola fazendo passagens do pé em torno dela), de controle da bola (chutinhos), de diferentes dribles (chapeuzinho, fintas etc.), de passes com o peito do pé, de calcanhar, de cabeceio, de recepção da bola no peito ("arrematar no peito") e chute, enfim, de diferentes possibilidades de uso do corpo/bola no futebol. Mas, se o grupo aumentava com a chegada de pelo menos mais duas/três pessoas, novo jogo podia ser criado. Afinal, onde havia um grupo de jovens e uma bola havia sempre um peruzinho/bobinho. ${ }^{9}$

No decorrer da pesquisa de campo, chamou atenção a intensidade do envolvimento dos jovens nessas práticas. Rotineiras e exclusivamente masculinas, a maioria delas não possuía denominação específica entre os "nativos". Por ocasião do registro das notas de campo, a esse tipo de engajamento na prática do futebol demos o nome de ensaios. Isso

8 De fora é a denominação dada aos jovens ou grupos de jovens que aguardam a vez de jogar. Uma de fora é formada sempre que o número de praticantes interessados em participar do futebol excede o número de jogadores definido para o jogo.

9 Em círculo, os jovens trocavam passes entre si, ao mesmo tempo em que impediam que um dos jogadores (o peruzinho/bobinho) alcançasse a bola. Quando o peruzinho/bobinho conseguia tocar a bola, imediatamente, trocava de posição e o último jogador a tocá-la tornava-se o novo peruzinho/bobinho indo para o centro do círculo. No jogo era permitido usar (no toque com a bola) as mesmas partes do corpo que é permitido usar no jogo de futebol: pés, cabeça, peito, coxa, etc. Nunca reter ou tocar a bola com as mãos. Tratava-se de um jogo que podia ser realizado em qualquer lugar e que, muitas vezes, era usado como uma prévia para a organização de outros jogos (era aquecimento para os jogos oficiais, era jogo "pré-desportivo" no projeto social, era tempo de espera da pelada, era espaço de transição dos jogadores de fora). Porém, mais do que isso, o peruzinho/bobinho também possuía uma lógica de organização própria - não apenas de prévia dos jogos que lhe sucediam. 
nos permitia expressar uma forma específica de interação do jogador com a bola e com os outros jogadores. Foi na leitura do texto de Ingold (2000, 2001), entretanto, que encontramos reforço para o uso dessa denominação. Assim, uso o termo ensaio duplamente: como expressão do dado de campo e como incursão teórica.

Segundo o autor (2001, p. 21) a aprendizagem (ou processo de habilitação que se constitui na prática) envolve observação e imitação. A imitação não é, contudo, "uma transcrição automática de dispositivos cognitivos de uma cabeça para outra" (INGOLD, 2001, p.130 ${ }^{10}$. Ela é um processo "desenvolvimental" que ocorre em um ambiente, ou seja, a imitação - que envolve tarefas repetidas e exercícios - é um aspecto da vida da pessoa no mundo. ${ }^{11}$ Tomando como exemplo as práticas do ferreiro, Ingold (2001, p. 21) afirma que seus movimentos não podem ser entendidos como produto de um "programa motor fixado" conseguidos "através de aplicação de uma fórmula". Mais do que "mera" execução técnica, as mãos do ferreiro são guiadas pela percepção e a repetição rítmica do movimento é constituída na interface com o ambiente (INGOLD, 2000, p. 190). Carregados de intenção, os movimentos são continuamente responsivos a cada mudança de situação (INGOLD, 2000, p. 414) e, desse modo, são sempre diferentes (em relação ao anterior), pois se efetivam em condições ambientais diferentes a cada momento. O que o praticante faz, quando parece apenas repetir, são "ajustamentos" contínuos do movimento no curso da tarefa emergente. Assim, a performance exige habilidade de coordenar ação/percepção (INGOLD, 2001, p. 23 - 24).

Para Ingold (2000, p. 414), a constituição da habilidade (do ferreiro, por exemplo) não se dá espontaneamente, sem preparação. Ao contrário, ela envolve muita prática, exige ensaio. Segundo o autor (2001, p. 131) as capacidades de percepção e ação, nas diferentes práticas humanas (como andar, atirar, reter etc.), são constituídas por meio da prática e do treino no ambiente característico da atividade e, sobretudo, sob a orientação/ guia dos mais experientes. O ensaio - ou processo de "repetir o mesmo movimento como uma preparação ou condução para o seu desempenho prático" (INGOLD, 2000, p. 418) - é, então, a experiência de movimentos em diferentes circunstâncias/ambientes. Na conceituação do autor, o ensaio é tratado como forma fundamental de aprendizagem, ou seja, como processo de incorporação a partir do exercício de mergulho no que se está aprendendo. O ensaio é, então, uma forma de entendimento na prática. Nas palavras do autor (2000, p. 416), o tipo de know-how alcançado no contexto da prática é "processo de habilitação, no qual a aprendizagem é inseparável do fazer".

Iniciados na infância, os ensaios constituem experiências masculinas no futebol, que se desdobram no decorrer de todo o processo de participação na prática social. A recorrência nos relatos dos praticantes e a redundância nas notas de campo permitiram compreender que se tratava de práticas ordinárias entre os jovens do bairro. É como relatou Schiva:

10 Contrapondo-se à ciência cognitiva convencional Ingold (2001), Maturana e Varela (2005), Varela (1992) questionam abordagens sobre a aprendizagem como aquisição de representações separada do fazer.

11 "Sem dúvida, pessoas criadas em diferentes ambientes aprendem a perceber o seu entorno, e a agir dentro dele, de diferentes modos" (INGOLD, 2001, p.134). 
Quatro anos eu tinha quando meu pai me deu uma bola. [...] Já brincava de ficar jogando. Era uma bola de plástico. Eu ficava brincando, jogando na parede para a bola voltar em mim e eu ficava brincando, chutando de qualquer jeito, derrubando as coisas da minha mãe dentro de casa. (Grifos meus)

Os ensaios futebolísticos faziam parte das interações masculinas cotidianas em casa, na rua, na escola, no campo de futebol etc. Mesmo sem um espaço/tempo específico, sem a presença de um mestre/professor, os ensaios de futebol eram práticas fluídas, difusas que conjugavam aspectos aparentemente inconciliáveis: a aprendizagem se dava de forma intensa e, ao mesmo tempo, opaca, porque, fora das situações de ensino, a aprendizagem ganhava pouca visibilidade.

Uma singularidade dos ensaios - que os tornava atraentes, sobretudo para os iniciantes - era que neles o jogo de corpo realizado, ocorria, predominantemente, fora das situações de competição (e/ou ritual) inerente ao esporte. Como um jogo-exercício para todas as configurações do futebol, não havia entre os jogadores, portanto, uma preocupação imediata com vencer. Nos ensaios de futebol (em que pegar o jeito do corpo se sobressaía aos demais aspectos da prática social) não estava em questão a superação do outro, mas a superação dos limites que separam a bola do corpo. ${ }^{12}$ Isso não quer dizer que se tratava de práticas fáceis e/ou repetitivas. Os movimentos futebolísticos produzidos pelos jovens do bairro nos ensaios eram dinâmicos e complexos. Por exemplo: receber passes de diferentes modos (rasteiro, meia altura, alto etc.), de diferentes parceiros, de diferentes lugares do campo, em diferentes velocidades e forças imprimidas à bola, em diferentes contextos etc., implicava a execução de diferentes movimentos dos praticantes. Portanto, os jovens não estavam fazendo sempre a mesma coisa. Nas horas que passavam trocando passes, chutando e/ou realizando manobras com a bola, eles estavam ensaiando ou tentando repetir o resultado da ação sob condições adversas. Assim, mais que repetição/ reprodução, os jovens exercitavam/experimentavam o futebol e, desse modo, aprendiam a coordenar os movimentos do corpo. Como afirma Ingold (2000, p. 190), colocar o foco sobre o caráter habilitado das práticas humanas (e não no produto final) é fundamental para a compreensão do processo, porque o que se repete a todo o momento é o resultado do movimento, e não o movimento em si. Sendo assim, é o foco do observador que causa a impressão imediata de repetição/reprodução de movimentos.

Apesar dos praticantes que consideravam o futebol inato, o movimento futebolístico não vinha naturalmente. Os ensaios no bairro Universitário eram, pois, um importante modo de incorporação da habilidade futebolística: uma forma de aprender que envolvia esforço e ludicidade. A importância dessas práticas para a aprendizagem do futebol foi destacada pelo professor de Educação Física da escola do bairro:

Você pode pegar o menino que nunca foi a uma escolinha de futebol e que já sabe dominar a bola e chutar. A maioria já aprende, jogando bola na rua, jogando em 
casa, chutando em parede. O pai pega e vai ensinar, ele aprende isso tranquilo. [...] eu nunca fui a uma escolinha. Na aula de educação física o professor não ensinava isso para a gente: no rola bola. Então, chutando a bola na parede, é chutando que você aprende a dominar, chutar com o pé, depois que você vai ver. (Grifos meus)

A narrativa do professor, somada às observações de campo, suscitam ao menos duas reflexões sobre os ensaios de futebol, como modo de aprendizagem. A primeira é, conforme já foi dito, a importância dessas práticas como experiências fundamentais à incorporação do jogo (por exemplo: domínio). A segunda é que, apesar da multiplicidade de práticas que podem estar sob a denominação ensaios, pode-se dizer que havia pelo menos dois tipos de ensaios no bairro pesquisado: ensaios "solo" ("chutando a bola na parede, chutando que você aprende a dominar") e os ensaios "guiados": ("O pai vai ensinar"). São esses tipos ou situações de produção dos ensaios a que passamos a dar relevo.

\section{"Tem hora que eu fico fazendo exercício": ensaios "solo"}

Os ensaios "solo", neste trabalho, são aqueles em que o praticante, no empenho de movimentar-se com a bola, seguia realizando práticas futebolísticas sozinho. Nesse tipo de ensaio, a ausência de uma relação imediata com outro praticante não significava falta de referência. Pelo contrário: as jogadas de sucesso amplamente divulgadas na mídia e os lances dos mais experientes do futebol local eram fomentadores de múltiplos ensaios entre os praticantes. O relato de Pelé, que diariamente tentava com afinco, realizar movimentos futebolísticos diferentes, é um exemplo.

Tem hora que eu fico... faço ali só uma coisa, só para conseguir, até eu conseguir. [...] Lá dentro da casa, lá dentro de casa tem espaço aí eu só fico chutando na parede, brincando assim com a bola, fazendo um tanto de coisas com a bola, tem hora que eu fico fazendo exercício, fico fazendo um tanto de coisas. (Grifos meus)

Passar muito tempo chutando uma bola na parede (como descreveu Pelé) pode até parecer uma prática simples ou de menor importância, quando se tem como horizonte a complexidade do jogo de futebol. Contudo aprender a mover-se num espaço limitado, aprender a situar-se em relação às outras pessoas e outras práticas que ocupavam o mesmo contexto, aprender a desviar a bola de objetos ou mesmo impedir que ela ultrapassasse o muro de casa, aprender a imprimir força e direção adequada à bola e, ao mesmo tempo, acertá-la num ponto "ideal" ou que a permitisse retornar sob condição de domínio são apenas aspectos desse tipo de prática que permitem perceber a complexidade da atividade. Exercitando-se na parede, o praticante buscava a construção de um domínio dos movimentos do corpo com a bola (na relação com o entorno). ${ }^{13}$ De outro modo, é importante

13 Conversando com um professor de Educação Física (que quase chegou a jogar futebol profissionalmente e que colaborou com esta pesquisa, fazendo a leitura desta parte do trabalho) sobre os ensaios, ele falou sobre 
ressaltar também que, mesmo quando Pelé realizava seus ensaios de futebol, ele tinha a sua disposição um conhecimento coletivo.

Produzir (no próprio corpo) gestos futebolísticos de outros exigia ensaio exaustivo. Afinal, para os praticantes, não bastava conseguir realizar determinado movimento uma vez (como um golpe de sorte que, no bairro, é o mesmo que "cagada"). Era preciso que esse movimento passasse a fazer parte do rol de movimentos de que o praticante pudesse valer-se em situações da convivência com os pares, na prática social. Portanto, em situações específicas de jogo e em contextos onde era solicitado a demonstrar o domínio do gesto futebolístico. Esses contextos de sociabilidade juvenil do bairro se tornavam contextos de encenações de virilidade/masculinidade (FARIA, 2009). Além disso, os ensaios de futebol funcionavam como possibilidade de exibições de habilidade, da perícia do jogador com a bola. Era com essa motivação que Pelé investia tempo e energia nos ensaios: "até eu conseguir".

Como Pelé, muitos outros jovens do bairro passavam muito tempo realizando ensaios "solo": chutinhos/controle, chutes na parede, pedaladas, chapéu, peripécias de equilíbrio (a bola no pescoço, nas costas, na cabeça etc.). É a importância dessas práticas, tão visível e intensa no cotidiano dos jovens (e tão invisível como modo de aprendizagem para muitos praticantes) que parece ter sido antevista por Biruga (técnico do Racing Infantil e Juvenil). Para ele é no processo de execução que os jovens aprendem a perceber o corpo: "[...] é, ficam chutando, chutando, ele dá um chute, ele vê como ele chutou, e ele vai lembrar se ele pôs pouca força, se ele pôs a perna ou não". Biruga confirmou também que os movimentos futebolísticos realizados pelos jovens no cotidiano (os ensaios) não eram repetitivos. Mais do que isso, ele descreveu como é sutil, dinâmico e complexo o processo de aprendizagem disposto nos ensaios. Assim, a cada execução o praticante observava, realizava um tipo de cálculo, que tinha como referência experiências prévias (não apenas suas) e produzia mudanças/ajustes do movimento no curso da atividade. A esse tipo de procedimento, que possui transformações na prática, Maturana (2001, p.72) chama de recursão. Em outras palavras, o conjunto de movimentos produzidos por esses jovens no cotidiano - que aos olhos de outros aparenta um processo meramente repetitivo - é um procedimento recursivo, onde cada gesto produzido "faz referência à aplicação de uma operação sobre o resultado da aplicação de uma operação".

O relato de Biruga confirmava também que a habilidade se constitui da ampla experimentação do e no futebol e que esse processo é repleto de intencionalidade, como sugere Ingold $(2000,2001)$. Era repetido/ensaiando e deixando-se guiar por suas observações, que os iniciantes gradualmente sentiam as coisas por si mesmos (INGOLD, 2001, p. 21 - 22). Os ensaios futebolísticos dos jovens estavam, portanto, distantes de um mero processo de cópia ou, no sentido limitado do termo, de um tipo de reprodução da cultura. Pelo contrário, nessas práticas futebolísticas recursivas a cultura era um processo. Realizando os ensaios, os jovens constituíam uma corporeidade futebolística que - impregnada do contexto - era também singular. A cultura se constituía nesse exercício. 


\section{"Ensino ele posicionamento pra chutar a bola": ensaios "guiados"}

Muitos ensaios de futebol no bairro pesquisado ocorriam com a participação de mais de um praticante. Esse tipo de contexto era bastante profícuo à ocorrência de ensaios "guiados": alguém procurava orientar o ensaio de um iniciante ou menos experiente. Essa prática podia acontecer em vários contextos de produção de futebol do bairro. Por exemplo: nos ensaios dos alunos que participavam do Projeto Social no campo de futebol do Racing, Lúcio (que muitas vezes permitia que os jovens realizassem suas práticas de futebol "livremente") e outros praticantes faziam intervenções pontuais:

Há poucos alunos para participar do futebol no Projeto Esporte Esperança/Segundo Tempo no campo do Racing. Lúcio (professor do Projeto) entrega uma bola aos jovens e fica a distância conversando com Mário e observando as práticas dos jovens. Os jovens iniciam uma movimentação do futebol próximo ao gol. Várias vezes deixam a bola correr para as posições de escanteio e, com indicações dos colegas (sobre como e onde jogar), realizam o chute. Se a jogada é realizada com sucesso, todos comemoram. Outra movimentação que se repete é a tentativa de formas diferentes de chutes a gol (quando os jogadores também levantam a bola para que os colegas possam realizar gols de bicicleta, de cabeça, etc.). Um dos jogadores pede que o colega chute a bola impondo nela o movimento de rotação na hora do chute (tentativa de gol olímpico). Após a execução, o jogador afirma: "Quase deu". São raros os momentos de silêncio. Tudo é feito com indicações (sinalizadas com gestos e fala) sobre como realizar os movimentos futebolísticos entre os jogadores. Lúcio permanece todo o tempo dentro do campo observando à distância. De repente, ele diz a um jogador que erra o cabeceio: "- O cabeceio é assim, oh!" (monstra com gesto). Os jovens seguem realizando diferentes jogadas por longo tempo. [...]

Como nos ensaios "solo", nos ensaios "guiados", os praticantes podiam, a cada execução, realizar tentativas, "corrigir" o corpo na relação com a bola, descobrir como fazer, com "infinitos" acertos e erros. Nos encontros juvenis em que "a bola rolava", os praticantes mais experientes ajudavam os demais a compreender como abordar a bola, como posicionar o corpo para realizar embaixadas, como posicionar-se em campo, como chutar, por exemplo. Essas situações de produção do futebol, que ocorriam com frequência no bairro, mostravam que a aprendizagem do futebol fazia parte da sociabilidade.

Outra forma de aprendizagem que ocorria nos ensaios "guiados" tinha por referência a performance imediata dos veteranos. Como guias para a participação dos iniciantes, os veteranos funcionavam como modelos da prática - o que fazia muitos jovens prestar atenção neles. Nesses contextos, a presença do outro funcionava também como presença motivadora da performance. Assim, o jovem que seguia observando/observado caprichava, empenhava-se na realização de cada gesto.

Ensaios repetidos à exaustão - como afirma Damo (2005, p.285), repetidos até que o praticante começasse a "pensar corporalmente, antecipando se possível, as ações"14

14 A essa capacidade de agir prontamente Varela (1992, p.19) denominou presteza para ação. 
— ocorriam no âmbito da casa (com pais, irmãos, primos, tios etc.) e proximidades (com colegas de rua e da escola), no cotidiano escolar (com colegas de turma nas aulas de Educação Física e no recreio), no campo de futebol (com colegas de pelada, de time de várzea e do Projeto Social) etc. Nas muitas peripécias dos jogadores com a bola (que podiam se tornar pauta de longas conversas), eles criavam, experimentavam e imitavam jogadas. Como a possibilidade de inventar e experimentar raramente motivava exclusões, nos ensaios também se buscava (re)produzir (ou trazer para o próprio corpo/incorporar) as jogadas espetaculares da mídia. Assim, situações de pedaladas, dribles etc., eram constantemente exibidas/aprimoradas por veteranos e experimentadas por iniciantes. Como um jogo de "pegar o jeito", nos ensaios "guiados" os jovens também realizavam jogadas do futebol com jogadores posicionados em campo (cobrança de falta, pênalti, lateral, escanteio eram comuns). Esse amplo processo de experimentação permitia a execução do movimento futebolístico num jogo de "ajustamento rítmico de percepção e ação" (INGOLD, 2001, p.135).

Um foco mais aprofundado nos ensaios mostrou também que outras aprendizagens estavam em questão. O ensaio "guiado" que segue narrado por Cadu (17 anos) serve como exemplo emblemático: ${ }^{15}$

Igual o meu primo, meu primo vai fazer 07 anos, se não me engano. Ele começou a jogar bola com 4 anos. Ele não gostava de bola assim. Eu comecei a jogar, hoje ele não larga a bola, hoje ele dorme com a bola. Agora mesmo, ele está estudando, cinco e meia ele chega: "- ô Cadu, vamos lá fora". Eu tenho a maior paciência, o irmão dele não. [...] Ensino ele posicionamento para chutar a bola, ensino ele a bater chutinho, já bate chutinho já, 7 anos, pequenininho, vai fazer 7 anos[...]. Brinco com ele, falo com ele sobre a boleragem e tal, tipo assim, você tem [...], falo com ele, "- Tem que ser humilde, Douglas". Igual ele fica virando a cara assim, que todo jogador faz, eu acho ruim isso. [...] Tipo assim, pega na bola assim, toca e vira a cara, discriminando o outro jogador, aí o outro jogador pode apelar. Igual ele fica brincando assim e virando a cara, eu: “- Não Douglas, vamos ter humildade e tal". Ensino ele só o básico, ele já quer pedalar, já quer fazer tudo. [...] Chutar para o gol, posicionamento, chutar com a outra perna. Desde agora isso, desde agora chutar com a outra perna, já está chutando com a outra perna, quando eu vou brincar com ele aqui fora, e ele vai chutar com a direita: “- Eu não. Vou parar. Tem que chutar com a esquerda". Para ele ir aprendendo". (Cadu) (Grifos meus)

Praticando futebol no terreiro de casa ou na rua, Cadu e Douglas repetiam movimentos básicos do futebol (Cadu orientava Douglas sobre posicionamento do corpo), movimentos de domínio do futebol (por exemplo, chutinhos) e aprimoravam a execução de movimentos bilaterais (o uso das pernas esquerda e direita). As indicações de Cadu ajudavam Douglas a constituir uma percepção do seu corpo/movimento na relação com a

15 Cadu é um jovem que se destaca nas práticas futebolísticas do bairro: sempre está inserido nos jogos cotidianos (raramente fica na "de fora"), faz parte do time juvenil do Racing como titular e já atua como reserva no Júnior do Racing. Segundo ele, várias vezes foi convidado para compor times que poderiam rende-lhe inserção profissional. Chegou a treinar, por exemplo, no Cruzeiro Esporte Clube, mas foi prejudicado por seu porte físico: Cadu é "baixinho". 
bola e o ambiente. Um tipo de exercício prático que não comportava dicotomias (corpo/ mente, biologia/cultura, pensamento/ação, ensino/aprendizagem etc.), Cadu tentava orientar Douglas na difícil tarefa de aprender a dominar o próprio corpo e o jogo.

Os ensaios cotidianos de futebol, que ocupavam importante parte da vida dos dois, permitiam que Douglas fosse constituindo a habilidade sob a orientação de Cadu. Nesse contexto de interações, a aprendizagem ultrapassava aspectos técnicos. Mais do que orientar Douglas na execução das técnicas futebolísticas, o que Cadu fazia era explicitar aspectos velados da prática social, a complexidade que envolve o jogo: a ética do futebol que requer do praticante senso de humildade incorporado. Traduzindo um tipo de resposta ética, no futebol o praticante tem que conseguir comunicar não apenas verbalmente, mas também corporalmente, o respeito para com o outro - aspectos também observados por Varela (1992) ao estudar a competência ética ${ }^{16}$.

Entendendo que a forma de se expressar no futebol (verbal e gestualmente) era inadequada à participação mais abrangente na prática social, Cadu mostrava a Douglas que, o que ele estava fazendo para afirmar-se no campo futebolístico (sobrepujando explicitamente o outro com a mania de "boleragem") estava fazendo de forma equivocada/grotesca. A pretensa superioridade tão almejada pelos praticantes do jogo não seria, portanto, alcançada dessa maneira. Pelo contrário. Se, no futebol, era permitido sobrepujar/humilhar o outro, isso não podia ser feito de maneira explícita, como Douglas estava fazendo. Era necessário, pois, que ele aprendesse a se situar nesse campo de relações que constitui o futebol sem infringir regras básicas (do jogo e as sociais). Sobrepujar e humilhar o outro só é permitido de maneira velada: uma passada de bola entre as pernas, um "chapéu", uma "canetada" (drible), um sorriso contido etc. Jamais de forma direta. Cadu queria de Douglas, portanto, mais que postura física, uma postura ética em relação ao futebol.

Esse tipo de habilidade que Cadu queria que Douglas constituísse não é obtido por meio de informações livrescas ou transmitido pela oralidade em formas convencionais de instrução. Disposto no próprio corpo do praticante, era, pois, um conhecimento incorporado que exigia o envolvimento prático - que Douglas jamais encontraria fora da prática social. ${ }^{17}$ Cadu não criava, contudo, situações para ensinar a Douglas determinados aspectos do futebol. As orientações emergiam das interações na prática. Assim, por exemplo, foi motivado pela "boleragem" de Douglas que Cadu expôs seus conhecimentos sobre o campo esportivo/futebolístico - o que é completamente diferente de uma aula teórica sobre o futebol no Brasil ou de um exercício com a finalidade de ensinar. Como a aprendizagem em Alcoólicos Anônimos, descrita por Lave e Wenger (1991) — em que os "veteranos que

16 Varela (1992, p. 14), no desenvolvimento do trabalho sobre a competência ética, toma como ponto de partida as contribuições recentes da fenomenologia e do pragmatismo e daquilo que define como "tríade de sabedoria: confucianismo, taoísmo e busdismo". Um importante ingrediente do seu trabalho é o "esforço de evidenciar contribuições não-ocidentais, adotando, portanto um ponto de vista comparativo relativamente à experiência ética". A tese de partida do autor é que "a ética está mais próxima da sabedoria do que da razão, mais próxima da compreensão de que a coisa deve ser o bem do que da formulação de princípios corretos" (p.13).

17 Isso, segundo Damo (2005, p. 176), dificulta a reconversão de jogadores profissionais. Segundo o autor "as possibilidades de reconversão dos capitais futebolísticos são restritas, visto que os investimentos são demasiadamente especializados para servirem ao que quer que seja para além do futebol". 
atuam como padrinhos (sponser) dão aos iniciantes avisos e instruções apropriados para os passos seguintes" e os contêm a espera de que "estes se tornem preparados para um próximo passo através de uma participação crescente na comunidade" (Lave e Wenger, 1991, p. 92) - nos ensaios cotidianos Cadu "guiava" os passos de Douglas no fluxo da prática emergente.

Era o "engajamento atento e situado" na prática que permitia que Douglas (e também Cadu) constituíssem a habilidade (INGOLD, 2001). Sobre esse processo, Ingold (2001) traz contribuições singulares. Segundo o autor (2001, p. 138), o "conhecimento na história de vida da pessoa não é um resultado de uma transmissão de informação, mas de uma redescoberta guiada". Como ocorreu entre Cadu e Douglas, o conhecimento se constitui no próprio sujeito, na interação com os predecessores e sob a sua direção. Para Ingold (2001, p. 14) "o processo de aprendizagem pela redescoberta guiada é mais competentemente conduzido pela noção de execução". Assim, diz o autor:

[...] o iniciante observa, sente, escuta os movimentos do expert, e procura por meio de experiências repetidas executar o seu próprio movimento [...] para alcançar um tipo de ajustamento rítmico da percepção e ação que liga ao centro da performance fluente. (INGOLD, 2001, p. 141). (Tradução minha)

Como Cadu e Douglas, muitos jovens se envolviam em múltiplos ensaios "guiados" no cotidiano do Universitário. Neles, mesmo com diferentes tipos de participação no futebol, se elaborava no corpo a habilidade para o jogo. Afinal não importava ser iniciante, iniciado ou veterano. Havia sempre o que melhorar no futebol: o manejo com a bola, o domínio refinado do corpo ou leitura do corpo do outro, a compreensão mais ampla da prática futebolística. Diferente das relações pedagógicas, nos ensaios "guiados" a reciprocidade era o que movia a participação. Quem participava/praticava aprendia:

Eu gosto de chutar no gol de falta, de pênalti, essas coisas aí eu gosto. [...] Drible também. Drible, nós ficamos brincando com meu primo, ele fica nervoso comigo porque eu driblo ele toda hora, ele só fica me batendo (ar de satisfação) brincando. [...]. Eu brinco muito com minha família, a minha família é grande tem muitos meninos, e nós brincamos juntos, toda mão na quadra. Tem vez que eu consigo ensinar, meus irmãos. [...] Meu irmãos pequenos. Ah, fico ensinando como que é para fazer. Tem hora que ele erra, eu falo, vou te ensinar como é que é heim, e ensino ele. Igual ele me ajuda e eu ajudo ele. [...] Quando eu estou querendo brincar ele brinca comigo, ele vai no gol e eu fico chutando nele, senão eu fico no gol e ele fica chutando em mim. Eu brinco muito com minha família, a minha família é grande tem muitos meninos, e nos brincamos junto, toda mão na quadra.(Pelé) (Grifos meus)

Aqui em casa tem essa varanda aqui, só que ela era mais ampla, aí eu chamava minha irmã, meu primo de 12 anos, que eles não tem uma malandragem no futebol, jogavam os quatro contra mim e eu ficava driblando para sempre eu estar aprimorando, vinham os quatro eu driblava os quatro, vinham os dois, eu driblava os dois. E eles sempre que a gente estava brincando, eu sempre aprimorando o drible também jogando contra eles porque eles não tem uma noção muito boa do 
futebol. Eles sabem que futebol você tem que fazer o gol dentro de uma casinha e pronto, eles não sabem distinguir uma falta de alguma coisa. Eu sempre chamava eles para brincar para poder estar aprimorando drible, aprimorando chute, esses negócios ${ }^{18}$.(Schiva) (Grifos meus)

\section{"Ele prefere a bola que um prato de comida": o sentido dos ensaios}

Computando o tempo de envolvimento dos praticantes nos ensaios, é possível perceber que não se tratava de uma tarefa insignificante ou destituída de intencionalidade, porque envolvia completamente os praticantes. Essa imersão cotidiana é relatada pela mãe de um jovem (Cadu):

Nóh! A vó dele brigava porque ele ficava jogando bola no terreiro, quebrava os vidros tudo da casa da vó dele. Quebrava os vidros da casa do tio dele [...] O negócio dele era bola. Ele ia chegando da escola e ia procurando a bola. Até hoje, hoje ele fica aqui, daí a pouquinho na hora que o meu sobrinho chega ele vai lá para rua ficar jogando bola com ele. [...] Ele chega aqui, daí a pouquinho ele fala assim, vou lá no campo jogar uma bola. Ele não perde a mania de bola de jeito nenhum; ele prefere a bola do que um prato de comida [...]. (Dona Eduarda) (Grifos meus)

Nos ensaios, os jovens do bairro (tal como Cadu) investiam tempo e energia, e levavam a sério a tarefa de domínio/constituição do próprio corpo no futebol. A busca de know-how mobilizava-os nessas práticas. Segundo Varela (1992, p. 28) - que toma de empréstimo a distinção entre know-how e know-what de Dewey - pode dizer-se que, mediante os nossos hábitos, "sabemos como comportar-nos". Assim, passeamos, lemos em voz alta, entramos e saímos do ônibus, vestimo-nos e despimo-nos, "em suma, fazemos uma infinidade de atos úteis sem neles pensar". Para Varela (1992, p. 28) esse tipo de conhecimento - "capacidade de confronto imediato" que não implica em uma reflexão e uma valoração consciente - é corporificado na prática.

Justamente porque percebiam que nos ensaios estavam aprendendo, os jovens eram, tomados pelo processo: um exercício do corpo e da masculinidade. A intencionalidade dos ensaios, ou o que movia o empenho dos praticantes, era, portanto, a constituição de um tipo de relação afinada e profícua entre corpo/movimento, bola e ambiente. Em outras palavras: jovens que realizavam ensaios se imbuíam da tarefa de compreender o futebol. Mas, não pelo pensamento abstrato e, sim, pela própria ação.

Os jovens do bairro Universitário se engajavam nos ensaios porque era isso que se esperava deles (porque há um discurso social de que homem tem que jogar futebol), mas também por outros motivos. Os praticantes do futebol realizavam ensaios pelo prazer de produzir o próprio corpo (habilidade). Para eles, quanto maior era a complexidade da

18 Esse é a único relato que menciona a presença de mulheres nos ensaios de futebol. No cotidiano do bairro é rara essa participação. Uma situação específica, da qual tenho registro, ocorreu na escola quando algumas jovens participaram de um jogo de peruzinho/bobinho com os meninos. 
tarefa, maior era o empenho de realização e, consequentemente, a satisfação da conquista. A recompensa vinha da incorporação de um gesto difícil (como uma vitória sobre si mesmo) e do sentimento de pertencimento - uma alegria geralmente esboçada em grito de comemoração, sorriso, ou até mesmo seriedade que não combinava. Era como se estivessem afirmando em silêncio: "- Normal!".

Quando, por exemplo, a bola ia "redondinha", cumprir o objetivo do jogador, a festa era geral. Até quem estava assistindo sorria e/ou fazia algum tipo de comentário: "-É isso aí, fulano!"; “-Que é isso, veio!"; “- Estilo Romário!". Muitos jovens se empolgavam e até aplaudiam os colegas que conseguiam acertar o tempo da bola, realizar jogadas "bonitas" dos jogadores profissionais e/ou de repercussão na mídia. De outro modo, às vezes, ajudavam (mesmo com demonstrações) os colegas/jogadores com dificuldades na realização de uma dada jogada, um tipo de chute, um cabeceio etc. Nesse contexto os praticantes eram também movidos por admiração pelos que constituíram habilidade (reconhecimento de que se tratava de algo difícil) e pela expectativa de serem também admirados/afirmados.

\section{CONSIDERAÇÕES FINAIS}

Nos ensaios os jovens se tornavam e eram, ao mesmo tempo, tornados jogadores. Como pianistas que "não precisam construir mãos para tocar, mas levam anos e anos criando mãos pianistas" ("fortes, destras, calibradas no espaço, com uma extraordinária precisão"), os praticantes do futebol no bairro Universitário não precisavam construir pernas para jogar, mas transformá-las em "pernas de jogadores" (fortes, ágeis, rápidas e lépidas). ${ }^{19}$ Para isso era necessário dedicação, era necessário um esforço invisível. Para transformar gestos grotescos e desajeitados em habilidade futebolística, como quem bricola o futebol no corpo, a repetição não só era fundamental, como também era inovadora, ou seja, ela era prenhe de invenção. Compreendendo a aprendizagem como imersão e invenção, Kastrup (2005, p. 1278), ajuda a refletir sobre esse processo:

A sedimentação do aprendizado ocorre por intermédio da repetição e do ritmo de um treino que se dá por meio de um conjunto de sessões consecutivas e regulares. O sentido do treino é criar um campo estável de sedimentação e acolhimento de experiências afectivas ${ }^{20}$ inesperadas, que fogem ao controle do eu. A regularidade das sessões tem como efeito a criação de uma familiaridade com experiências de breakdown/pertubações e enfim, o desenvolvimento de uma atitude cognitiva e atencional ao plano das forças. O processo começa com esforço, por intermédio de uma atitude consciente e intencional, mas que se torna, com a prática, espontânea e initencional. ${ }^{21}$

19 Depraz, Varela \& Vermersch (2003 apud Kastrup, 2005, p 1278).

20 Afectiva como algo que afeta o sujeito/corpo, sendo por ele incorporado.

21 Contrária à noção de que a aprendizagem que se faz sobre o corpo não envolve invenção, Kastrup (2005, p. 1278 - 1279) recorre à origem latina da palavra: invenção (invenire) significa compor com restos arqueológicos. Quanto ao exemplo do pianista, a autora afirma que as mãos "não são uma invenção ex-nihilo nem se definem 
Nas múltiplas maneiras de jogar futebol, os jovens praticantes iam realizando ensaios como exercício de iniciação, de permanência e também de especialização no futebol. Mas, a falta de tradição de considerar essas práticas como práticas de aprendizagem tornava invisível essa constituição da habilidade futebolística. Além disso, esses praticantes as intercalavam com a participação em outros futebóis.

Mas, se os ensaios são fundamentais para o aprendizado desse esporte, a eles esse processo não se reduz. O Currículo de aprendizagem do futebol inclui, de maneira fundamental, a participação dos jovens do bairro nos diferentes jogos que compõem o cotidiano (nas peladas, jogos das aulas de Educação Física e Recreios, jogos de rua, campeonatos etc.) e também outros contextos de sociabilidades produzidas pelo jogo (bate papo com os amigos, participação nas torcidas, assistir as partidas no campo do bairro e na escola etc.). É nesse amplo processo de participação, que envolve experimentações, repetições (ensaio) e orientação constante de praticantes mais experientes, que os jovens constituem a habilidade futebolística. Constituem, portanto, o futebol ao constituir a si próprios.

\section{REFERÊNCIAS}

DAMO, Arlei Sander. Do dom à profissionalização: uma etnografia do futebol de espetáculo a partir da formação de jogadores no Brasil e na França. 2005. Tese (Doutorado em Antropologia) - Universidade Federal do Rio Grande do Sul (FRGS); Instituto de Filosofia e Ciências Humanas, Porto Alegre, 2005.

FARIA, E. L.; FONTES, J. C. Os jovens e a produção do futebol na cidade: apropriações, sociabilidades e aprendizagens. In: DEBORTOLI, José Alfredo Oliveira; MARTINS, Maria de Fátima Almeida; MARTINS, Sergio (Org.). Infâncias na Metrópole. Belo Horizonte: UFMG, 2008, p. 147-173.

FARIA, E. L. Jogo do corpo e corpo do jogo: futebol e masculinidade. Cadernos de Campo. São Paulo, USP, v. 18, p. 65-86, 2009.

INGOLD, Thin. The perception of the environment: essays on livelihood, dwelling and skill. New York: Routledge, 2000.

INGOLD, Thin. From the transmission of representations to the education of attention. In: . The debated mind: evolutionary psychology versus ethnography. Oxford: Harvey Whitehouse, 2001.

INGOLD, Thin. Beyond art and technology: the anthropology of skill. In: SCHIFFER, M. B. Anthropological perspectives on technology. Albuquerque (NM): University of New Mexico Press, 2001.

KASTRUP, Virgínia. Políticas cognitivas na formação do professor e o problema do devirmestre. Educação e Sociedade, Campinas, v. 26, n. 93, p.1273-1288, set./dez. 2005.

por seu aparato biológico". "Elas (que se definem pela destreza, firmeza, precisão e perícia de movimentos dos dedos) são cuidadosamente produzidas". [...] 
maio/2018

KASTRUP, Virgínia. A aprendizagem da atenção na cognição inventiva. Psicologia e Sociedade. Porto Alegre, v. 16, n. 3, p. 7-17, set./dez. 2004.

LAVE, Jean; WENGER, Etiene. Situated learning: legitimate peripheral participation. Cambridge, UK: Cambridge University Press, 1991.

MATURANA, Humberto R. e VARELA, Francisco. J. A árvore do conhecimento: as bases biológicas da compreensão humana. Tradução de Humberto Mariotti e Lia Diskin. 5. ed. São Paulo: Palas Athena, 2005.

MATURANA, Humberto R. Cognição, ciência e vida cotidiana. Tradução de Cristina Magro e Victor Paredes. 5. ed. Belo Horizonte: Editora UFMG, 2001.

MELUCCI, Alberto. Juventude, tempo e movimentos sociais. Revista Brasileira de Educação. ANPED, n. especial, p. 5-14, 1997.

SAUTCHUK, Carlos Emanuel. Aprendizagem como gênese: prática, skill e individuação Horizontes Antropológicos, Porto Alegre, ano 21, n. 44, jul./dez. 2015.

SPÓSITO, Marilia Pontes. Estudos sobre a juventude em educação. Revista Brasileira de Educação. ANPED, n. especial, p. 37- 52, 1997.

VARELA, Francisco. J. Sobre a competência ética. Tradução de Artur Mourão. Lisboa: Edições 70, 1992. 